\title{
Trends and Causes of Farmers Suicide in Maharashtra State, India
}

\author{
Prof. Vikas V. Ade
}

Assistant Professor, Political Science, C. J. Patel Arts, Comm. \& Science College, Tirora, Dist. Gondia, Maharashtra, India

\begin{abstract}
Article Info

Volume 8 Issue 1

Page Number: 248-261

Publication Issue :

January-February-2021

\section{Article History}

Accepted : 20 Feb 2021

Published : 28 Feb 2021

The present study accepted out with an investigative strategy of social research on farmer's suicide trend in Maharashtra state, Over 15,000 farmers have committed suicide in Maharashtra between 2013 and 2018. In Vidarbha and Marathwada from January 2001 to July 2018, a total of 29602farmers from 18 districts of died by suicide. About $83.74 \%$ of the state's total farmer suicides were in the two regions of Vidarbha and Marathwada. The highest farmer suicide in Amravati division is 57.8\%, than Nagpur division 15.6\%, Aurangabad division 13.6\%, Nasik division 8.3\%, Pune division $4.5 \%$ and lowest farmer suicide $0.8 \%$ in Konkan division. A farming disaster has rainfall a spate of suicides in Maharashtra. The suicide mortality rate for farmers in the state has increased from 2001 to 2018. The rain dependent cotton growing farmers of Maharashtra are faced with declining profitability because of dumping in the global market by the US, low import tariffs, failure of the Monopoly Cotton Procurement Scheme and withdrawal of the state are resulting in declining public investment in agriculture, poor government agriculture extension services and the diminishing role of formal credit institutions. The farmer is faced with yield, price, credit, income and weather uncertainties. The way out is to merge bold public policy initiatives with civil society engagement.
\end{abstract}

Keyword : - Maharashtra State, Geo-Political View, Farmers' Suicide.

\section{INTRODUCTION}

Geographic and demographic variations in suicide rates have continued to be noted in Australian farmers $(32,37,38)$. Taking person and place into account, and noting the importance of community and environmental contexts on well-being, have been cited as critical to any future rural suicide prevention intervention $(5,7,13)$. Farmers do not just belong to an occupational group, but are part of families, small and often tight-knit rural communities, and operate within a unique geographical, psychological, environmental and social context within Australia. The farmers' work environment has been described as characterised by "high stress". with "relentless demands". Social factors such as relationship 
breakdown, isolation and loneliness, as well adherence to sociocultural norms of masculinity, stoicism and self-reliance have been implicated in Australian farmer suicide $(6,8,9,31)$. Farmers themselves perceive risk for suicide to result from a highly interactive combination of individual, environmental and social factors Risk of suicide in farmers has 'been recognised to be higher than in other occupations in Australia and some countries across the world 12, 14, 30, 29). Whilst well documented, the phenomena of rural suicide remains poorly understood. Geographic and demographic variances in Australian farmer suicide cases suggest we need to look more carefully at the complex interaction of factors at play if targeted prevention strategies are to be developed and delivered to those most at risk (28, 15, 20, 27). Farmers impression a repeated sense of impossibility due to the loss of crops, dwindling income levels, shrinking lands and even the loss of a way of life $(16,18,19,21)$. Another factor that increases suicides is the probable for social segregation developing from the loss of communities as well as geographical remoteness. Rising trend of nuclear families leading to non-sharing of problems or tensions causes mental stress. The lack of access to mental health services in rural areas and the stigma attached to treatment is also a contributing factor.

\section{OBJECTIVES}

\section{The objectives of the study are as follows:}

$>$ To look into the trends and patterns of the recent suicide scenario in Maharashtra.

$>$ To study the Geo-political situation of Maharashtra State.

$>$ To identify and examine other socio-economic factors leading to suicidal death by the deceased farmers.

\section{METHODS}

Focus groups were conducted in three diverse sites across two states in Maharashtra with trend and pattern 2001 to 2018, separately to gain perceptions about suicide risk and protective factors and attitudes towards suicide and help seeking. All data collected on census of India, Divisional Commission rate Office, Aurangabad and Nagpur etc.

\section{RESULT AND ANALYSIS}

\section{Brief History of Maharashtra:-}

During the 18th century almost all of western and central India, as well as large segments of the north and east, was brought under the suzerainty of the Maratha confederacy, an alliance formed after Shivaji's kingdom had collapsed. Europeans, however, had been present along the coast since the early 16th century. Britain gained control of Bombay Island in 1661, and from the early 19th century onward the Marathas gradually succumbed to British expansion on the mainland. The British proceeded to establish an administrative province known as the Bombay Presidency. After India gained its independence in 1947, the province became Bombay state (1950). A number of former princely states (notably Baroda [now Vadodara]) subsequently were merged into the new state. On November 1, 1956, in a major linguistic and political reorganization of the states of peninsular India, Bombay state received large parts of Madhya Pradesh, as well as the northwestern portion of the dismembered Hyderabad state (which had been formed after Indian independence from the former Hyderabad princely state). The outcome of that reorganization, however, was still a linguistically divided state, in which most of the Gujarati-speaking peoples lived in the north and most of the Marathispeaking peoples lived in the south. Demands by the two language groups that the state be divided into two parts resulted, on May 1, 1960, in the creation of Gujarat in the north and the newly renamed 
Maharashtra in the south. Bombay, remaining part of Maharashtra, became the new state's capital.

\section{Geographical Profile:-}

The word Maharashtra, the land of the Marathi speaking people, appears to be derived from Maharashtri, an old form of Prakrit. Some believe that the word indicates that it was the land of the Mahars and the Rattas, while others consider it to be a corruption of the term 'Maha Kantara' (the Great Forest), a synonym for 'Dandakaranya' (Fig. 1).

\section{The Land:-}

Located in the north centre of Peninsular India, with a command of the Arabian Sea through its port of Mumbai, Maharashtra has a remarkable physical homogeneity, enforced by its underlying geology. The dominant physical trait of the state is its plateau character. The Maharashtra Desh is a plateau of plateaux, its western upturned rims rising to form the Sahyadri Range and its slopes gently descending towards the east and southeast. The major rivers and their master tributaries have carved the plateaux into alternating broad-river valleys and intervening higher lever interfluves, such as the Ahmednagar, Buldana, and Yavatmal plateaux. The Sahyadri Range is the physical backbone of Maharashtra. Rising on an average to an elevation of $1000 \mathrm{~m}$. it falls in steep cliffs, to the Konkan on the west. Eastwards, the hill country falls in steps through a transitional area known as Mawal to the plateau level. The series of crowning plateaux on the crest forms a distinctive feature of the Sahyadri Range. The Konkan, lying between the Arabian Sea and the Sahyadri Range is narrow coastal lowland, barely $50 \mathrm{~km}$. wide. Though mostly below $200 \mathrm{~m}$., it is far from being a plain country. Highly dissected and broken, the Konkan alternates between narrow, steep-sided valleys and low laterite plateaux. The Satpudas, hills along the northern border, and the Bhamragad-Chiroli-
Gaikhuri Ranges on the eastern border form physical barriers preventing easy movement, but also serve as natural limits to the state.

\section{Geology and Topography:-}

Except around Mumbai, and along the eastern limits, the State of Maharashtra presents a monotonously uniform, flat-topped skyline. This topography of the state is the outcome of its geological structure. The state area, barring the extreme eastern Vidarbha region, parts of Kolhapur and Sindhudurg, is practically co-terminous with the Deccan Traps. Roughly 60 to 90 million years ago, the outpouring of basic lava through fissures formed horizontally bedded basalt over large areas $(10,11,26)$. Variations in their composition and structure have resulted in massive, well-jointed steel-grey cliff faces alternating with structural benches of vesicular amygdaloid lava and ash layers, all of which contribute to the pyramida-shaped hills and crest-level plateaux or mesas. Earth sculpturing under the tropical climate completed the panorama-sharply defining the landform features in the semi-arid conditions, and rounding the hilltops under wetter condition. Fluvial action by the Krishna, Bhima, Godavari, Tapi-Purna and Wardha-Wainganga river $(21,22,25)$ systems has further aided in the compartmentalisation of the Desh into broad, open river valleys, alternating with plateau interfluves, that form the ribs of the Sahyadrian backbone. In sharp contrast, the hill torrents of the Konkan, barely a $100 \mathrm{~km}$. long, tumble down as roaring streams which flow in deeply entrenched valleys to terminate in tidal estuaries.

\section{Climite:-}

The state enjoys a tropical monsoon climate; the hot scorching summer from March onwards yields to the rainy monsoon in early June. The rich green cover of the monsoon season persists during the mild winter that follows through an unpleasant October transition, but turns into a dusty, barren brown as the summer sets in again. The seasonal rains from the 
western sea-clouds are very heavy and the rainfall is over $400 \mathrm{~cm}$., on the Sahyadrian crests $(23,24)$. The Konkan on the windward side is also endowed with heavy rainfall, declining northwards. East of the Sahyadri, the rainfall diminishes to a meagre $70 \mathrm{~cm}$. in the western plateau districts, with SolapurAhmednagar lying in the heart of the dry zone. The rains increase slightly, later in the season, eastwards in the Marathwada and Vidarbha regions. The highly pulsatory character of the monsoon, with its short spells of rainy weather and long dry breaks, floods, as well as droughts add much to the discomfort of the rural economy.

\section{Resources:-}

The total population of Maharashtra is 11.42 crores in 2011 (Table 1). Forests comprising only 17\% of the state area cover the eastern region and the Sahyadri Range, while open scrub jungle dots the plateaux. If Maharashtra represented the Maha Kantara in the historic past, today little of it is left; vast sections have been denuded and stripped of the vegetal cover. The soils of Maharashtra are residual, derived from the underlying basalts. In the semi-dry plateau, the regur (black-cotton soil) is clayey, rich in iron, but poor in nitrogen and organic matter; it is moisture-retentive. Where redeposited along the river valleys, those kali soils are deeper and heavier, better suited for rabi crops. Farther away, with a better mixture of lime, the morand soils form the ideal Kharif zone. The higher plateau areas have pather soils, which contain more gravel. In the rainy Konkan, and the Sahyadri Range, the same basalts give rise to the brick-red laterites productive under a forest-cover, but readily stripped into a sterile varkas when the vegetation is removed. By and large, soils of Maharashtra are shallow and somewhat poor. Water is the most precious natural resource of the state, greatly in the demand, and most unevenly distributed. A large number of villages lack drinking water, especially during the summer months, even in the wet Konkan. Barely $11 \%$ of the net sown area is irrigated. Perched water tables in the basalt aquifers have contributed to increased well irrigation, which accounts for approximately $55 \%$ of the irrigable water. The granitic-gneissic terrain in the eastern hilly area of Vidarbha accounts for all tank irrigation. Tube-wells in the Tapi-Purna alluvium and shallow wells in the coastal sands are the other main sources of water. The mineral-bearing zones of Maharashtra lie beyond the area of the basalts in eastern Vidarbha, southern Kolhapur and the Sindhudurg area. The Chandrapur, Gadchirali, Bhandara and Nagpur Districts form the main mineral belt, with coal and manganese as the major minerals and iron ore and limestone as potential wealth. The Ratnagiri coast contains sizeable deposits of illimenite.

\section{Politics of Maharashtra:-}

Politics of Maharashtra and List of Chief Ministers of Maharashtra .The politics of the state in the first decades after its formation in 1960 were dominated by the Indian National Congress party or its offshoots such as the Nationalist Congress Party, but since the 1990s Hindu parties have dominated. In the early years, politics of Maharashtra was dominated by Congress party figures such as Yashwantrao Chavan, Vasantdada Patil, Vasantrao Naik and Shankarrao Chavan. Sharad Pawar, who started his political career in the Congress party, has been a towering personality in the state and national politics for over forty years. During his career, he has split the Congress twice with significant consequences for the state politics.The Congress party enjoyed a near unchallenged dominance of the political landscape until 1995 when the Shiv Sena and the Bharatiya Janata Party (BJP) secured an overwhelming majority in the state to form a coalition government. After his second parting from the Congress party in 1999, Sharad Pawar founded the NCP but then formed a coalition with the Congress to keep out the BJP-Shiv Sena combine out of the Maharashtra state government for fifteen years until September 2014. Prithviraj Chavan of the Congress party was the last Chief Minister of Maharashtra under the Congress / NCP alliance. For the 2014 assembly polls, the two 
alliances between NCP and Congress and that between BJP and Shiv Sena respectively broke down over seat allocations. In the election, the largest number of seats went to the Bharatiya Janata Party, with 122 seats. The BJP initially formed a minority government under Devendra Fadnavis.The Shiv sena entered the Government after two months, and provided a comfortable majority for the alliance in the Maharashtra Vidhansabha for the duration of the assembly. In 2019 Lok sabha elections, the BJP-Shiv Sena alliance secured 41 seat out 48 from the state. Later in 2019, the BJP and Shiv Sena alliance fought the assembly elections together but the alliance broke down after the election over the post of chief minister. Uddhav Thackeray of Shiv Sena then formed an alternative governing coalition under his leadership with his erstwhile opponents from NCP, INC, and a number of independent members of legislative assembly. On 28 November 2019, Thackeray took oath as 19th Chief minister of Maharashtra after being elected as the president of the newly formed coalition named Maha Vikas Aghadi.

\section{State representation in Indian Parliament:-}

The people of Maharashtra also elect 48 members to the Lok Sabha, the lower house of the Indian Parliament. In the 2014 general elections, the National Democratic Alliance (NDA), consisting of the Bharatiya Janata Party, the Shiv Sena, and Swabhimani Paksha, won 23, 18, and 1 seats, respectively. The NDA retained its dominance in the state by winning 41 out of the 48 seats in the 2019 Lok Sabha elections. The members of the state Legislative Assembly elect 19 members to the Rajya Sabha, the upper house of the Indian Parliament.

\section{Local government:-}

A Gram panchayat office in a Abdul Lat village, Kolhapur district The state has a long tradition of highly powerful planning bodies at district and local levels. Local self governance institutions in rural areas include 34 zilla parishads (district councils), 355 Taluka Panchayat samitis (district Sub-division councils) and 27,993 Gram panchayats (village councils). Urban areas in the state are governed by 27 Municipal Corporations, 222 Municipal Councils, four Nagar Panchayats and seven Cantonment Boards.[100][134] Although Maharashtra had Gram panchayat with elected members since 1961, the 73rd amendment to the Indian constitution of 1993 put in place a statutory requirement of $33 \%$ of seats on the panchayats reserved for women.In addition, 33\% of the sarpanch (panchayat chief) positions were also reserved for women. Although the amendment boosted the number of women leaders at the village level, there have been cases of harassment by male members of the panchayat towards the female members of the organisations.The administration in each district is headed by a District Collector, who belongs to the Indian Administrative Service and is assisted by a number of officers belonging to Maharashtra state services. The Superintendent of Police, an officer belonging to the Indian Police Service and assisted by the officers of the Maharashtra Police Service, maintains law and order in addition to other related issues in each district. The Divisional Forest Officer, an officer belonging to the Indian Forest Service, manages the forests, environment, and wildlife of the district, assisted by the officers of Maharashtra Forest Service and Maharashtra Forest Subordinate Service. Sectoral development in the districts is looked after by the district head of each development department, such as Public Works, Health, Education, Agriculture and Animal Husbandry.

\section{Judiciary:-}

The Bombay High Court, one of the most distinguished high courts in India The judiciary in the state consists of the Maharashtra High Court (The High Court of Bombay), district and session courts in each district and lower courts and judges at the taluka level. The High Court has regional branches at Nagpur and Aurangabad in Maharashtra and Panaji which is the capital of Goa. The state cabinet on 13 May 2015 passed a resolution favouring the setting up 
of one more bench of the Bombay high court in Kolhapur, covering the region. The President of India appoints the chief justice of the High Court of the Maharashtra judiciary on the advice of the chief justice of the Supreme Court of India as well as the Governor of Maharashtra. Other judges are appointed by the chief justice of the high court of the judiciary on the advice of the Chief Justice. Subordinate Judicial Service is another vital part of the judiciary of Maharashtra. The subordinate judiciary or the district courts are categorised into two divisions: the Maharashtra civil judicial services and higher judicial service. While the Maharashtra civil judicial services comprises the Civil Judges (Junior Division)/Judicial Magistrates and civil judges (Senior Division)/Chief Judicial Magistrate, the higher judicial service comprises civil and sessions judges. The Subordinate judicial service of the judiciary is controlled by the District Judge.

\section{Trends across Marathwada and Vidarbha:-}

The present study accepted out with an investigative strategy of social research on farmer's suicide trend in Maharashtra state, Over 15,000 farmers have committed suicide in Maharashtra between 2013 and 2018. In Vidarbha and Marathwada from January 2001 to July 2018, a total of 29602farmers from 18 districts of died by suicide. About $83.74 \%$ of the state's total farmer suicides were in the two regions of Vidarbha and Marathwada 1, 2, 3, 4). The highest farmer suicide in Amravati division is $57.8 \%$, than Nagpur division 15.6\%, Aurangabad division 13.6\%, Nasik division 8.3\%, Pune division 4.5\% and lowest farmer suicide $0.8 \%$ in Konkan division. A farming disaster has rainfall a spate of suicides in Maharashtra. The suicide mortality rate for farmers in the state has increased from 2001 to 2018 (Fig. 2). Farmer suicides are an unfortunate result of the agrarian distress plaguing the rural economy of many states of the country. Vidarbha (Table 2) and Marathwada (Table 3) regions in Maharashtra have recorded very high numbers of farmer suicides, and an attempt to calculate the number of suicides and the suicide mortality rate is the first step towards gaining an in-depth understanding of the prevalence and seriousness of the issue. An analysis of the data reveals the relationship between farmer suicides and issues such as monsoon failure, water shortage, drought, absence of social security, robust crop procurement mechanisms and increasing debt burdens. For over two and a half decades, suicides by the farming community in India have become a cause for concern At the all-India level, states like Andhra Pradesh, Karnataka and Maharashtra have become the hotspots of farmer suicides. This issue in India has triggered academic discourse, but very few public policy initiatives have been put forth to redress a problem of this magnitude. By now, it is clear that suicide by farmers is a complex phenomenon. It is easy to quantify the suicide deaths; however, it is difficult to decode the reasons in their entirety. It is estimated that during the period between 2001 and 2018 (Fig 3), the years of life lost on account of farmer suicides increased by $12 \%$. During the same period, India moved from the 20th to the eighth position in the global index of life lost due to suicides. As per the Global Burden of Disease (GBD) estimate of 2010, India accounts for $35.6 \%$ of the global years of life lost on account of suicides. It is more than double of its global population share. In India, the data on suicides is collected and published by the National Crime Records Bureau (NCRB). Information compiled by police stations goes to the respective state crime records bureau (SCRB)/criminal investigation department (CID) and then to the NCRB, which compiles information at the national level. However, in India, what is reported by the NCRB is just half of the GBD estimate. links such poor reporting to the Indian Penal Code, which holds suicide as a criminal act, 1 or to the society which often does not report a suicide to avoid social stigma. Further, it needs to be noted that suicides by cultivators and agricultural labourers cannot be termed as farmer suicides. This is because in India cultivators and agricultural labourers are two distinct groups of the rural population. In some countries, suicides by cultivators are included in 
suicides by agricultural workers. In Europe and North America, which have small population groups, suicide rates are computed for "farm population" that includes farm owners and workers. However, in the Indian context, cultivators and agricultural labourers being two distinctly large population groups cannot be clubbed together. Besides an economic dimension, such classification also has a social dimension. Another vital factor that complicates the estimation of farmer suicides in India is that in states like Maharashtra, a large number of them are categorised as ineligible suicides. The classification as eligible and ineligible farmer suicides has a significant connotation, especially when it comes to the ex-gratia compensation of 1 lakh granted by the state government to the family of a deceased farmer. For the administrative machinery, a farmer who dies by suicide but does not possess the 7/12 abstract in their name (a revenue department land record stating presumptive title of land ownership), is not deemed eligible to be treated as a farmer. In Maharashtra, the proportion of such cases is one of the highest. Thus, farmer suicides at the state level and thereby at the all-India level are grossly underestimated. Accordingly, this paper proceeds as follows. The following section articulates the methods of analysis and describes the sources of the data. The review of literature on farmers' suicides is discussed in the next section, while the regional profile of Marathwada and Vidarbha is given in the section following it. Moving further, an attempt is made to bring out the spatial and temporal analysis of the data pertaining to the various aspects of farmer suicides in the two regions of Marathwada and Vidarbha. The section after that focuses on the complexity of eligible and ineligible farmer suicides and the final section concludes the article.

\section{Farmers' Suicide Causes:-}

In the Maharashtra are various causes are environmental disasters economic imbalance, social and individual causes of farmers' suicide in Maharashtra.
1 Environmental Disasters:- The global warming are an effective agricultural production is mostly depends on favorable weather condition. Deforestation and other manmade reasons natural condition has become more worsen and reasons like heavy raining, floods, droughts, delay in raining, heavy cyclones etc. farmers unable to take qualitative and quantitative production from their farm. They again \& again put their all efforts in the agriculture. Continuous losses turn them to become insolvent and frustration of the same forces them to commit suicides $(33,35)$.

2. Crop letdown: - India is an agricultural land $65 \%$ of family depends on rain the probability of farming committing suicide is more during bad rain years. Inspire of the farmers work the production of the crop low which is also one of the basic causes of farmer's suicide

3. Thankfulness and low income: Rural farmers often become burdened with over debt. The farmers are indebted because of low income the farmers have to face many social and financial problems. To arrange dowry for daughter and sisters marriage much expenditure than income daily dispute in family inability to fulfill requirement of family members lead to farmer's suicide

4. Values of farm product:- The government does not seen to be paying attention to this vicious circle. Nobody has tried to fix the prices based on the cost of the agricultural production. It would be seen that in the last twenty years the prices of the farm product have relatively dropped as compare to the prices of other product. It is often seen that when sowing season for the kharif and rubi crops come the prices of the grains reach much more but when harvesting season comes the rate drops $(34,36)$.

5. Growth in cost of production:- The digging, soil maintenance, for insecticides, pesticides, cutting, transportation and selling of products requires money In addition to this hybrid seeds are also requires for good quality \& quantity of product, which are very costly and not affordable to marginal and poor farmers. Increase in cost of production which forces to farmers to commit suicide. 
6. Agriculture loan:- Farming related activities like taking bore well, pipeline setting purchasing seeds ,bees, tractors and others related things to the farm. But there are lot hindrances and impediments while sanctioning such lone amount to the farmers by bank finalizing all the related documents is almost like an ordeal. So most of the farmers at the critical time traditional source of money as like savkar , money lenders come to their help and sanctions loan immediately but charges interest at the very high rate even after accepting all such adversities a natural calamities make a great sabotage to the farm and finally the farmers are totally collapsed because not a single agro product is encased

7. Income disparities in economy:-Today, the person who is rich is becoming rich and one who is poor is becoming poor therefore the valley of reciprocal economy is increasing day by day so the farmers are turning to suicide.

8. Costly modern agriculture technique:- After the green revolution and innovation of new technologies new hybrid seeds, insecticides, pesticides and farm cultivation technologies makes farming more easier and production is increased considerably. But these technologies and innovations are so costly and not affordable to poor small and marginal farmers.

9. Additional Causes:-lack of basic infrastructural facilities like safe drinking water, inadequate health facilities, transport facilities, proper food, cloth and shelter affects on psychological and physical condition of the farmers. Sometimes they become drug addicted and drunker. All these things attracted heavy diseases and turn them to die.

Table No. 1 Population of Maharashtra districts 2011

\begin{tabular}{|c|c|c|c|c|c|c|c|c|c|}
\hline \multirow[t]{2}{*}{ Rank } & \multirow[t]{2}{*}{ District } & \multicolumn{6}{|c|}{ Papulaion } & \multicolumn{2}{|c|}{ Sex Ratio } \\
\hline & & Male & Female & Total & Share & Ural & Urban & $\begin{array}{l}\text { F- Per } \\
1000 \\
M\end{array}$ & $\begin{array}{l}\text { M- Per } \\
100 \mathrm{~F}\end{array}$ \\
\hline 1 & Thane & $5,865,078$ & $5,195,070$ & $11,060,148$ & 9.84 & 23.01 & 76.99 & 886 & 112.897 \\
\hline 2 & Pune & $4,924,105$ & $4,505,303$ & $9,429,408$ & 8.39 & 39.01 & 60.99 & 915 & 109.296 \\
\hline 3 & $\begin{array}{l}\text { Mumbai } \\
\text { Suburban }\end{array}$ & $5,031,323$ & $4,325,639$ & $9,356,962$ & 8.33 & 0.00 & 100.00 & 860 & 116.314 \\
\hline 4 & Nashik & $3,157,186$ & $2,950,001$ & $6,107,187$ & 5.43 & 57.47 & 42.53 & 934 & 107.023 \\
\hline 5 & Nagpur & $2,384,975$ & $2,268,595$ & $4,653,570$ & 4.14 & 31.69 & 68.31 & 951 & 105.130 \\
\hline 6 & Ahmadnagar & $2,342,825$ & $2,200,334$ & $4,543,159$ & 4.04 & 79.91 & 20.09 & 939 & 106.476 \\
\hline 7 & Solapur & $2,227,852$ & $2,089,904$ & $4,317,756$ & 3.84 & 67.60 & 32.40 & 938 & 106.601 \\
\hline 8 & Jalgaon & $2,197,365$ & $2,032,552$ & $4,229,917$ & 3.76 & 68.26 & 31.74 & 925 & 108.109 \\
\hline 9 & Kolhapur & $1,980,658$ & $1,895,343$ & $3,876,001$ & 3.45 & 68.27 & 31.73 & 957 & 104.501 \\
\hline 10 & Aurangabad & $1,924,469$ & $1,776,813$ & $3,701,282$ & 3.29 & 56.23 & 43.77 & 923 & 108.310 \\
\hline 11 & Nanded & $1,730,075$ & $1,631,217$ & $3,361,292$ & 2.99 & 72.81 & 27.19 & 943 & 106.060 \\
\hline 12 & Mumbai & $1,684,608$ & $1,400,803$ & $3,085,411$ & 2.75 & 0.00 & 100.00 & 832 & 120.260 \\
\hline 13 & Satara & $1,510,842$ & $1,492,899$ & $3,003,741$ & 2.67 & 81.01 & 18.99 & 988 & 101.202 \\
\hline 14 & Amravati & $1,480,768$ & $1,407,677$ & $2,888,445$ & 2.57 & 64.09 & 35.91 & 951 & 105.192 \\
\hline 15 & Sangli & $1,435,728$ & $1,386,415$ & $2,822,143$ & 2.51 & 74.51 & 25.49 & 966 & 103.557 \\
\hline 16 & Yavatmal & $1,419,965$ & $1,352,383$ & $2,772,348$ & 2.47 & 78.42 & 21.58 & 952 & 104.997 \\
\hline 17 & Raigarh & $1,344,345$ & $1,289,855$ & $2,634,200$ & 2.34 & 63.17 & 36.83 & 959 & 104.225 \\
\hline 18 & Buldana & $1,337,560$ & $1,248,698$ & $2,586,258$ & 2.30 & 78.78 & 21.22 & 934 & 107.116 \\
\hline
\end{tabular}




\begin{tabular}{|l|l|l|l|l|l|l|l|l|l|}
\hline 19 & Bid & $1,349,106$ & $1,235,943$ & $2,585,049$ & 2.30 & 80.10 & 19.90 & 916 & 109.156 \\
\hline 20 & Latur & $1,273,140$ & $1,181,056$ & $2,454,196$ & 2.18 & 74.53 & 25.47 & 928 & 107.797 \\
\hline 21 & Chandrapur & $1,123,834$ & $1,080,473$ & $2,204,307$ & 1.96 & 64.82 & 35.18 & 961 & 104.013 \\
\hline 22 & Dhule & $1,054,031$ & 996,831 & $2,050,862$ & 1.83 & 72.16 & 27.84 & 946 & 105.738 \\
\hline 23 & Jalna & $1,011,473$ & 947,573 & $1,959,046$ & 1.74 & 80.73 & 19.27 & 937 & 106.744 \\
\hline 24 & Parbhani & 942,870 & 893,216 & $1,836,086$ & 1.63 & 68.97 & 31.03 & 947 & 105.559 \\
\hline 25 & Akola & 932,334 & 881,572 & $1,813,906$ & 1.61 & 60.32 & 39.68 & 946 & 105.758 \\
\hline 26 & Osmanabad & 861,535 & 796,041 & $1,657,576$ & 1.48 & 83.04 & 16.96 & 924 & 108.227 \\
\hline 27 & Nandurbar & 833,170 & 815,125 & $1,648,295$ & 1.47 & 83.29 & 16.71 & 978 & 102.214 \\
\hline 28 & Ratnagiri & 761,121 & 853,948 & $1,615,069$ & 1.44 & 83.67 & 16.33 & 1,122 & 89.130 \\
\hline 29 & Gondiya & 661,554 & 660,953 & $1,322,507$ & 1.18 & 82.92 & 17.08 & 999 & 100.091 \\
\hline 30 & Wardha & 668,385 & 632,389 & $1,300,774$ & 1.16 & 67.46 & 32.54 & 946 & 105.692 \\
\hline 31 & Bhandara & 605,520 & 594,814 & $1,200,334$ & 1.07 & 80.52 & 19.48 & 982 & 101.800 \\
\hline 32 & Washim & 620,302 & 576,858 & $1,197,160$ & 1.07 & 82.34 & 17.66 & 930 & 107.531 \\
\hline 33 & Hingoli & 606,294 & 571,051 & $1,177,345$ & 1.05 & 84.82 & 15.18 & 942 & 106.172 \\
\hline 34 & Gadchiroli & 541,328 & 531,614 & $1,072,942$ & 0.95 & 89.00 & 11.00 & 982 & 101.827 \\
\hline 35 & Sindhudurg & 417,332 & 432,319 & 849,651 & 0.76 & 87.41 & 12.59 & 1,036 & 96.533 \\
\hline
\end{tabular}

Table 2. Absolute and relative number of farmers' suicides in various divisions of Maharashtra.

\begin{tabular}{|l|c|c|c|c|}
\hline Division & $\begin{array}{c}\text { Number of } \\
\text { Farmers } \\
\text { Suicide }\end{array}$ & $\begin{array}{c}\text { Percent to } \\
\text { Total Number }\end{array}$ & $\begin{array}{c}\text { Liable for } \\
\text { grant }\end{array}$ & $\begin{array}{c}\text { Percent of } \\
\text { liable for } \\
\text { grant to total } \\
\text { suicides }\end{array}$ \\
\hline Konkan Division & 12 & 0.1 & 12 & 100 \\
\hline Pune Division & 585 & 4.6 & 321 & 54.9 \\
\hline Nasik Division & 1040 & 8.3 & 598 & 57.5 \\
\hline Aurangabad Division & 1713 & 13.6 & 866 & 50.55 \\
\hline Nagpur Division & 1967 & 15.6 & 796 & 40.5 \\
\hline Amravati Division & 7274 & 57.8 & 2469 & 33.9 \\
\hline Maharashtra & 12591 & 100 & 5062 & 40.2 \\
\hline
\end{tabular}

Table 3. Absolute and relative number of farmers' suicides in districts of Vidarabha.

\begin{tabular}{|l|c|c|}
\hline District & Farmers suicide & Percentage \\
& Number & 3.2 \\
\hline Napur & 403 & 6.3 \\
\hline Wardha & 789 & 2.6 \\
\hline Chandrapur & 323 & 0.5 \\
\hline Gadchiroli & 59 & 2.2 \\
\hline Bhandara & 280 & 0.9 \\
\hline Gondia & 113 & 14.3 \\
\hline Amravati & 1798 & 8.6 \\
\hline Akola & 1079 & . \\
\hline
\end{tabular}




\begin{tabular}{|l|c|c|}
\hline Buldhana & 1212 & 9.6 \\
\hline Yawatmal & 2289 & 18.2 \\
\hline Washim & 896 & 7.1 \\
\hline Vidarabha & 9241 & 73.5 \\
\hline
\end{tabular}

Table 4. Number of farmers suicides in Marathwada region

\begin{tabular}{|c|c|c|c|c|c|c|c|c|c|}
\hline Year & $\begin{array}{c}\text { Aurang } \\
\text { abad }\end{array}$ & Latur & Beed & $\begin{array}{c}\text { Prabhan } \\
\mathbf{i}\end{array}$ & Jalna & $\begin{array}{c}\text { Hingo } \\
\mathbf{l i}\end{array}$ & $\begin{array}{c}\text { Osmanab } \\
\text { ad }\end{array}$ & Nanded & Total \\
\hline 2010 & 02 & 04 & 79 & 22 & 04 & 02 & 23 & 55 & 191 \\
\hline 2011 & 00 & 04 & 73 & 23 & 06 & 05 & 25 & 33 & 169 \\
\hline 2012 & 02 & 00 & 91 & 35 & 06 & 03 & 22 & 39 & 198 \\
\hline 2013 & 04 & 03 & 98 & 17 & 08 & 02 & 29 & 146 & 207 \\
\hline 2014 & 56 & 44 & 152 & 70 & 32 & 31 & 71 & 118 & 574 \\
\hline 2015 & 144 & 106 & 301 & 104 & 83 & 41 & 164 & 190 & 1133 \\
\hline 2016 & 151 & 116 & 222 & 989 & 76 & 49 & 161 & 180 & 1053 \\
\hline 2017 & 139 & 94 & 207 & 125 & 91 & 56 & 126 & 153 & 991 \\
\hline Total & 498 & 371 & 1223 & 494 & 306 & 189 & 621 & 814 & 4516 \\
\hline
\end{tabular}

(Source: Divisional Commission rate Office, Aurangabad)

Table 5 Farmer Suicide in Maharashtra (2001-2018).

\begin{tabular}{|l|l|l|l|}
\hline Year & $\begin{array}{l}\text { Total No. of } \\
\text { Cases }\end{array}$ & Year & $\begin{array}{l}\text { Total No. of } \\
\text { Cases }\end{array}$ \\
\hline 2001 & 62 & 2010 & 1741 \\
\hline 2002 & 122 & 2011 & 1518 \\
\hline 2003 & 180 & 2012 & 1473 \\
\hline 2004 & 640 & 2013 & 1296 \\
\hline 2005 & 609 & 2014 & 1981 \\
\hline 2006 & 2376 & 2015 & 3228 \\
\hline 2007 & 2076 & 2016 & 3051 \\
\hline 2008 & 1966 & 2017 & 2917 \\
\hline 2009 & 1605 & 2018 & 2,761 \\
\hline & & Total & $\mathbf{2 9 6 0 2}$ \\
\hline
\end{tabular}




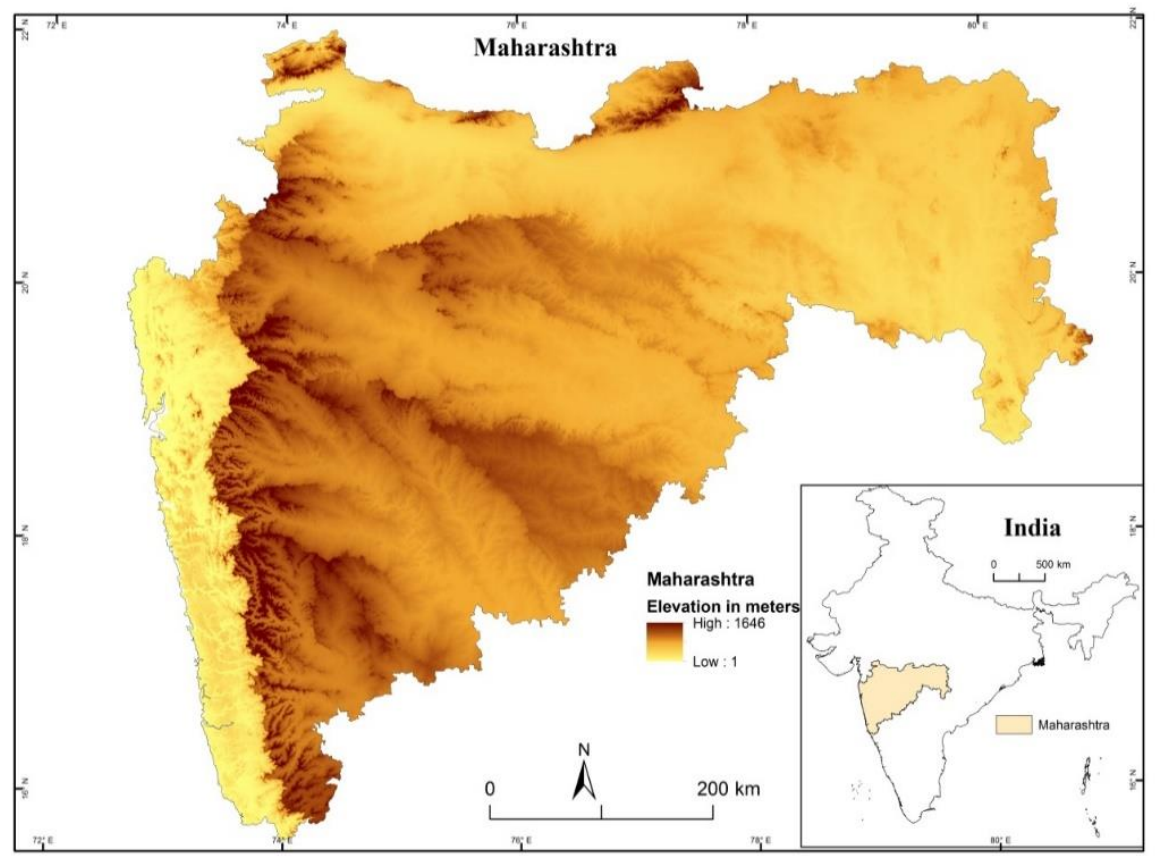

Fig. 1: Location Map Maharashtra State

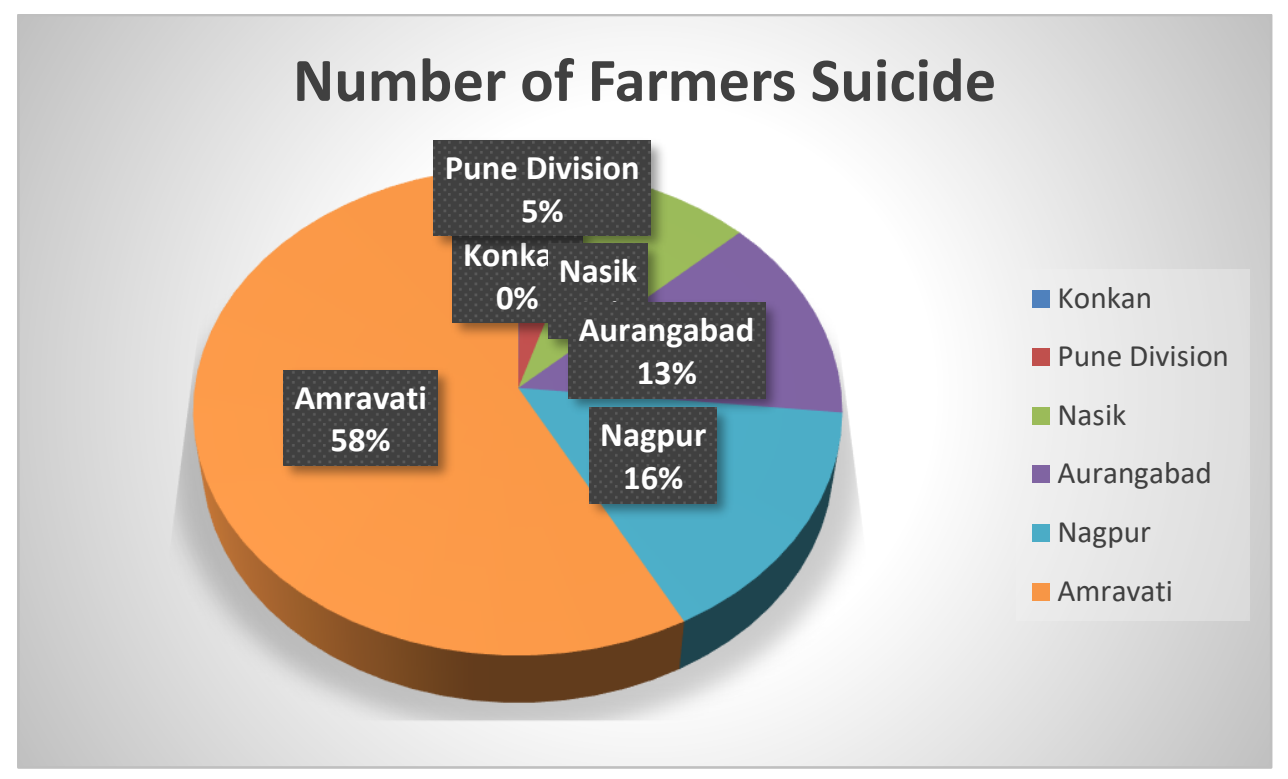

Fig. 2 Number of Farmers Suicide 


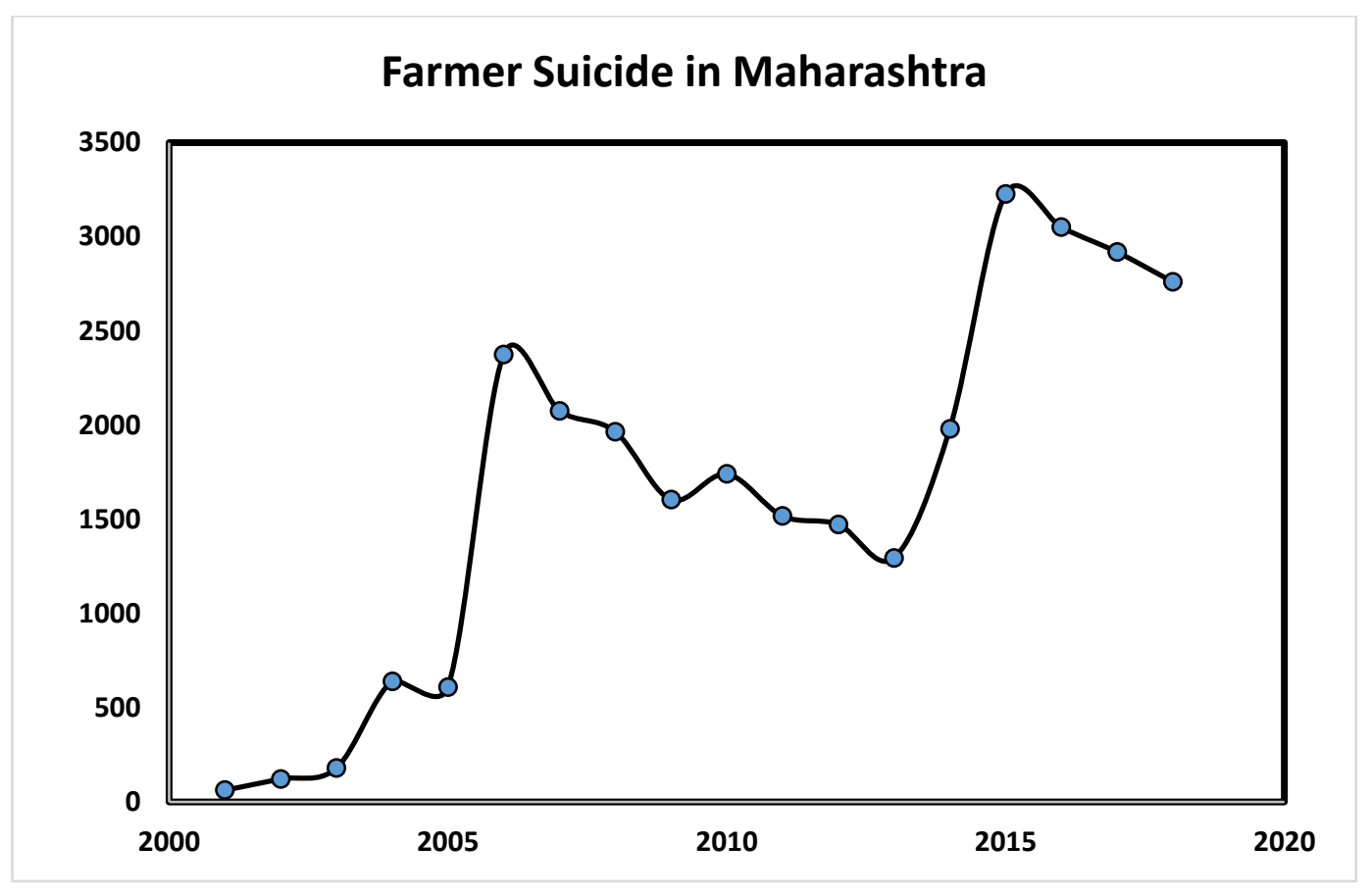

Fig. 3 Farmer Suicide in Maharashtra

\section{CONCLUSION}

Maharashtra has recorded as many as 32,605 farmer suicides in the 19-year span between 2001 and 2019, shows the latest state revenue department data. This means the average number of cases per year was 1,716. Overall, the number of farmer suicides in the state has shown a rise. Nearly 14,898 cases were reported in the fiveyear period between 2015 and This is a steep jump from 8,071 cases reported in the previous five years-2010 to 2014. As many as 9,272 farmer suicide cases were reported in the five-year period between 2004 and 2009, according to the data.The agriculture sector largely depends on rainy season. Rainy season plays critical role in the agriculture development of Maharashtra. On the basis of the result of the study it can be concluded that indebtedness, low productivity crop failure, more expenditure than income tension of daughter's marriage and continuous pressure from money lenders and banks persons for repayments etc. were the major causes of suicide of farmers. Farmers leader and social leaders should come together and help the farmers and should reduce the rate of suicide. So it is necessary to implement income generating activities which may reduce the farmer suicide. It is necessary to encourage the farmers to adopt allied activities like dairy, fishery and poultry etc. with farming activities. In order to solve the problem of farmers suicide a holistic approach is necessary.

\section{REFERENCES}

[1]. Ade V.V (2019): Farmers' Suicide In Vidarbha Region Of Maharashtra State: A Geo-Political View, Think India Journal, pp-12723-12732.

[2]. Ade V.V (2020): Farmers' Suicide In Marathawada Region Of Maharashtra State: A Geo-Political View, Our Heritage, Vol-68-Issue,pp- 1025110263.

[3]. Ade V.V (2015) : Human Right;s and India, Review Of Research Journal, Volume 4 Issue12,PP-1-06.

[4]. Ade V. V. (2019) Relevance of Mahatma Gandhi;s Economical Philosophy, Multidisciplinary International E-Research Journal Peer Reviewed Journal, Volume 203,Issue 06,PP-186-191

[5]. Alston M.( 2012) Rural male suicide in Australia. Soc Sci Med.;74(4):515-22. 
[6]. Andersen K, Hawgood J, Klieve H, Kõlves K, De Leo D, (2010): Suicide in selected occupations in Queensland: evidence from the state suicide register. Aust N Z J Psychiatry. https://doi.org/10.3109/00048670903487142.

[7]. Batterham P, Callear A, Christensen H. (2013) Correlates of suicide stigma and suicide literacy in the community. Suicide Life Threat Behav. 43(4):406-17.

[8]. Behere Prakash (2008): Farmers' suicide in Vidarbha region of Maharashtra state: A myth or reality, Indian Journal of Psychiatry 50(2):124-7, https:// doi:10.4103/0019-5545.42401

[9]. Bhattacharyya, S., Venkatesh, P., Aditya, K.S. et al. (2020). The Macro and Micro Point of View of Farmer Suicides in India. Natl. Acad. Sci. Lett. 43, 489-495 https://doi.org/10.1007/s40009-02000920-4

[10]. Bisen D.K and Kudnar N.S. (2013): A Sustainable Use and Management of Water Resource of the Wainganga River Basin: - A Traditional Management Systems. figshare. Journal contribution.

https://doi.org/10.6084/m9.figshare.663573.v1

[11]. Bisen D.K and Kudnar N.S. (2013): The production, export and cachment areas market of onion in indian agriculture, Research Expo International Interdisciplinary Journal, Volume III, Issue IV, pp-39-44.

[12]. Dandekar, A., Narawades, S., Rathod, R., Ingle, R., Kulkarni, V., \& Sateppa, Y. D. (2005): Causes of Farmer Suicides in Maharashtra: An Enquiry (Final Report Submitted to the Mumbai High Court). Tuljapur: Tata Institute of Social Sciences, Rural Campus.

[13]. Desai P. T. (2006): India Today, Farmers suicide. Delhi: Living Media India Ltd; February 27.

[14]. Deshpande, R. (2002). Suicide by Farmers in Karnataka: Agrarian Distress and Possible Alleviatory Steps. Economic and Political Weekly, 37(25): 2601-2610.

[15]. Gutierrez, A.P., Ponti, L., Kranthi, K.R. et al. (2020). Correction to: Bio-economics of Indian hybrid Bt cotton and farmer suicides. Environ Sci
Eur 32, 162 https://doi.org/10.1186/s12302-02000445-z

[16]. Hofle, A. (2015). Farmers' Suicides in India: A Methodological and Thematic Analysis in the State of Maharashtra (Master Thesis). South Asia Institute - Department of Anthropology, Heidelberg University.

[17]. Iyer, K., \& Manick, M. (2000). Impoverishment and Suicides in Rural Punjab. New Delhi: Indian Publishers Distributors.

[18]. Judd F, Jackson H, Fraser C, Murray G, Robins G, Komiti A.(2006) Understanding suicide in Australian farmers. Soc Psychiatry Psychiatr Epidemiol.;41(1):1-10.

[19]. Kennedy, A.J., Versace, V.L. \& Brumby, S.A. (2016) Research protocol for a digital intervention to reduce stigma among males with a personal experience of suicide in the Australian farming community. BMC Public Health16,1204. https://doi.org/10.1186/s12889-016-3874-3

[20]. Kleiman EM, Riskind JH, Schaefer KE, Weingarden H. (2012): The moderating role of social support on the relationship between impulsivity and suicide risk. Crisis. https://doi.org/10.1027/0227-5910/a000136.

[21]. Kudnar, N. S., (2017): Morphometric Analysis of the Wainganga River Basin Using Traditional \& GIS Techniques, Ph.D. Thesis, Rashtrasant Tukadoji Maharaj Nagpur University, Nagpur, Pp 66-250.

[22]. Kudnar, N. S., (2018): Water Pollution a Major Issue in Urban Areas: A Case Study of the Wainganga River Basin, Vidyawarta International Multidisciplinary Research Journal, pp 78-84.

[23]. Kudnar, N. S., (2019): Impacts of GPS-Based Mobile Application for Tourism: A Case Study of Gondia District, Vidhyawarta, Peer-Reviewed International Publication, pp-19-22.

[24]. Kudnar, N.S., (2020) GIS-based assessment of morphological and hydrological parameters of Wainganga river basin, Central India. Model. Earth Syst. Environ. 6, 1933-1950. https://doi.org/10.1007/s40808-020-00804-y

[25]. Kudnar, N.S. \& Rajasekhar, M, (2019): A study of the morphometric analysis and cycle of erosion in 
Waingangā Basin, India, Model. Earth Syst. Environ, pp-1-17.https://doi.org/10.1007/s40808019-00680-1

[26]. Kudnar, N. S. Padole, M. S et al (2021) "Traditional crop diversity and its conservation on-farm for sustainable agricultural production in Bhandara District, India", International Journal of Scientific Research in Science, Engineering and Technology (IJSRSET), Online ISSN: 2394-4099, Print ISSN : 2395-1990, Volume 8 Issue 1, pp. 3543, January-February 2021. Available at doi : https://doi.org/10.32628/IJSRSET207650

[27]. Milner A, Hjelmeland H, Arensman E, De Leo D. (2013): Social-environmental factors and suicide mortality: a narrative review of over 200 articles. Sociol Mind. https://doi.org/10.4236/sm.2013.32021.

[28]. Mishra, S. (2006) Suicide of Farmers in Maharashtra (Submitted to the Government of Maharashtra). Mumbai: Indira Gandhi Institute of Development Research.

[29]. Mishra, S. (2014). Farmers' Suicides in India, 1995-2012: Measurement and Interpretation (Asia Research Center Working Paper 62). London: London School of Economics \& Political Science Houghton Street.

[30]. Mohanty, B., \& Shroff, S. (2004). Farmer's Suicides in Maharashtra. Economic and Political Weekly, 39(52): 5599-5606.

[31]. National Crime Records Bureau (1999): Accidental Deaths and Suicides in India. Ministry Of Home Affairs. New Delhi: Government of India.

[32]. Perceval, M., Ross, V., Kõlves, K. et al. (2018) Social factors and Australian farmer suicide: a qualitative study. BMC Public Health 18, 1367. https://doi.org/10.1186/s12889-018-6287-7

[33]. Salunke V. S., Bhagat R. S. et al., (2020) Geography of Maharashtra, Prashant Publication, Jalgaon, pp- 1-229.

[34]. Salunke, V. S., Lagad, S. J., et al. (2021) "A Geospatial Approach to Enhance Point of the Interest and Tourism Potential Centers in Parner Tehsil in Maharashtra, India", International Journal of Scientific Research in Science, Engineering and Technology (IJSRSET), Online
ISSN : 2394-4099, Print ISSN : 2395-1990, Volume 8 Issue 1, pp. 186-196, Available at doi : https://doi.org/10.32628/IJSRSET218136

[35]. Sonawane, S.T. (2016) Critical Study of Farmers Suicide in Maharashtra- Causes and Remedies, International Journal of Innovative Research in Science, Engineering and Technology, Vol. 5, Issue $\quad 11, \quad$ pp-20150-20155. DOI:10.15680/IJIRSET.2016.0511149

[36]. Srinagesh Mannekote Thippaiah, Suresh Bada Math, Muralidhara Shankarapura Nanjappa (2019): Suicide in India: A preventable epidemic, The Indian Journal of Medical Research 150(4):324 https://doi.org/10.4103/ijmr.IJMR_1805_19

[37]. Taylor R, Page A, Morrell S, Harrison J, Carter G.(2005) Social and psychiatric influences on urban-rural differentials in Australian suicide. Suicide Life Threat Behav.;35(3):277-90.

[38]. Torok, M., Shand, F., Phillips, M. et al.(2019) Data-informed targets for suicide prevention: a small-area analysis of high-risk suicide regions in Australia. Soc Psychiatry Psychiatr Epidemiol 54, 1209-1218. https://doi.org/10.1007/s00127-01901716-8

\section{Cite this article as :}

Prof. Vikas V. Ade, "Trends and Causes of Farmers Suicide in Maharashtra State, India", International Journal of Scientific Research in Science, Engineering and Technology (IJSRSET), Online ISSN : 2394-4099, Print ISSN : 2395-1990, Volume 8 Issue 1, pp. 248-261, January-February 2021. Available at doi $\quad$ : https://doi.org/10.32628/IJSRSET218145 Journal URL : https://ijsrset.com/IJSRSET218145 